\title{
19. VOLCANICLASTIC CONSTITUENTS IN THE LEG 55 SEDIMENTS
}

\author{
Ivar Murdmaa, P. P. Shirshov Institute of Oceanology, U.S.S.R. Academy of Sciences, Moscow \\ and \\ G. P. Avdeiko, Institute of Volcanology, Far East Science Center, U.S.S.R. Academy of Sciences, \\ Petropavlovsk-Kamchatsky
}

\begin{abstract}
This chapter was previously intended to trace volcanic episodes through the Neogene and Pleistocene geological history recorded in the sedimentary sections drilled on the Emperor seamounts. Drilling disturbance, poor core recovery, and incomplete stratigraphic sections recovered from the seamounts have frustrated that plan, however. Moreover, the Leg 55 sedimentologists found in their smear-slide studies that transported island-arc tephra is scarce in the sediments, if present at all. So we have restricted our objective to description of the volcaniclastic admixture in sediments, as determined by mineralogical and geochemical data. We studied geochemistry of bulk samples (see Murdmaa et al., this volume), coarse-fraction mineralogy, and additional smear slides. The results obtained, however, do not tell much more about the volcaniclastic matter than did shipboard core descriptions.
\end{abstract}

\section{DISTRIBUTION AND COMPOSITION OF VOLCANICLASTIC MATTER}

The sediment section from Site 430 on Ōjin Seamount comprises Paleocene and Eocene shallow-water calcareous (clastic) ooze and sand, interbedded near the base with 11.8 meters of volcaniclastic sediments, containing, according to shipboard smear-slide descriptions, 60 per cent volcanic glass. The upper portion of the section in Hole 430 contains mixed Eocene to Recent microfossils, ice-rafted and local rock fragments, and manganese crusts and micronodules, and so represents a "non-depositional" environment on the guyot top. Except in the volcanic sand, volcanic glass occurs in small amounts (5\% or less, according to shipboard determinations).

We studied smear slides prepared from five samples used in geochemical bulk analysis of the Site 430 sediments (Murdmaa et al., this volume). The $\mathrm{Al}$ :Ti ratio in the sediments is low (4.1 to 6.4), indicating, along with the low $\mathrm{SiO}_{2}: \mathrm{Al}_{2} \mathrm{O}_{3}$ ratio (2.7 to 3.7$)$, that the nonbiogenic matter in the sediments is probably basaltic. In smear slides, badly altered volcaniclastic particles are common; these are yellowish brown or orange pelitic ferruginous (smectite?) aggregates. But true altered basalt fragments also occur, as do zeolite crystals and rare pyroxenes. Alteration of basaltic clasts to soil is confirmed by X-ray data (this volume) and by high $\mathrm{K}_{2} \mathrm{O}$ content with respect to $\mathrm{SiO}_{2}$ and $\mathrm{Al}_{2} \mathrm{O}_{3}$ contents.

A single coarse-fraction count (Table 1) shows a predominance of "unidentified" aggregate grains (mainly altered basaltic glass) in the light fraction, whereas iron oxides and "black opaques" (Fe-Mn crusts) constitute more than 80 per cent of the heavy fraction.

At Site 431, crushed manganese crusts, micronodules, zeolites, palagonite, and ice-rafted pebbles were recovered. The mixture contains Quaternary microfossils, and indicates a long-period "non-depositional" environment. Altered volcaniclastic constituents (phillipsite, palagonite) are undoubtedly older than the microfossils found in the cores.

Our four bulk analyses for Site 431 show low Al:Ti ratios (1.3 to 8.2$)$, indicating basaltic volcaniclastics. But the $\mathrm{SiO}_{2}: \mathrm{Al}_{2} \mathrm{O}_{3}$ ratio is rather high (4.0 to 4.9 ), perhaps because the samples contain terrigenous quartz and authigenic (?) chalcedony. In smear slides we found - along with ferromanganese crusts, phosphates, and calcareous clasts - yellowish brown, completely decomposed basaltic glass and smectite matrix, probably a weathering product of volcaniclastic matter.

At Site $\mathbf{4 3 2}$ on the Nintoku Seamount, a thin cover of Quaternary foraminiferal ooze is underlain by Eocene shallow-water calcareous ooze, volcanic sand, sandstone, and conglomerate (see core descriptions, this volume). A lateritic soil interbed, formed after basaltic volcaniclastic matter during subaerial weathering, occurs between two lava flows in Hole 432A. The volcaniclastic sand from Hole 432, according to shipboard smear-slide and thin-section descriptions, is composed of volcaniclastic (basaltic, weathered basaltic) particles, mixed with carbonate clasts, Mn micronodules, foraminifers, and quartz. In thin beds of volcanic sandstone and conglomerate just over basalts in Hole 432A, the volcanic particles, apparently epiclastic, are mixed with shallow-water benthic carbonate clasts, and are cemented by calcite.

A bulk analysis of calcareous-volcanic sand (see Murdmaa et al., this volume, table 1, Sample 432-1-4, $73-76 \mathrm{~cm}$ ) shows characteristic evidence of altered basalts: low Al:Ti ratio (6.6), high $\mathrm{K}_{2} \mathrm{O}$ and $\mathrm{Fe}_{2} \mathrm{O}_{3}$ contents. In the smear slide we found abundant yellowish brown aggregates and smectite (?) matrix of a similar color. The laterite soil sample is described in Murdmaa et al. (this volume).

In the upper (pelagic) section at Site 433 - lithologic Units 1 and 2 (upper Miocene to upper Pliocene) - volcaniclastic constituents are virtually absent, according to shipboard smear-slide descriptions (this volume). In a smear slide from the surface core of Hole 433, we found 
TABLE 1

Coarse-Fraction ( 0.1 to $0.05 \mathrm{~mm}$ ) Mineralogy

\begin{tabular}{|c|c|c|c|c|c|c|c|c|c|c|c|c|c|c|c|c|c|c|c|c|c|}
\hline \multirow[b]{2}{*}{$\begin{array}{l}\text { Sample, } \\
\text { Interval }(\mathrm{cm})\end{array}$} & \multicolumn{13}{|c|}{ Heavy Fraction } & \multicolumn{8}{|c|}{ Light Fraction } \\
\hline & 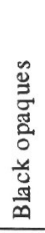 & 营 & $\begin{array}{l}\mathscr{y} \\
: \vec{x} \\
0 \\
0 \\
0 \\
L\end{array}$ & 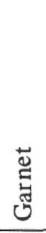 & 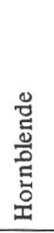 & 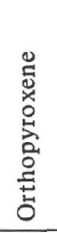 & 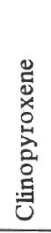 & 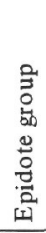 & 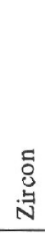 & 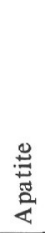 & 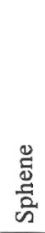 & 莺 & 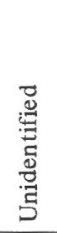 & 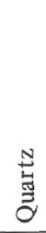 & 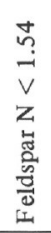 & 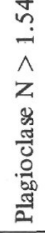 & $\begin{array}{l}\text { : } \\
0 \\
\text { N } \\
\text { N }\end{array}$ & 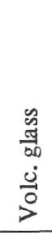 & 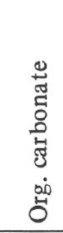 & 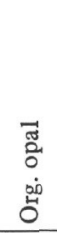 & 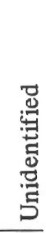 \\
\hline $430-2-1,52-60$ & 38 & - & 48 & 1 & 2 & 1 & 3 & 1 & + & + & - & - & 6 & 1 & + & 1 & - & - & 25 & - & 73 \\
\hline $432-1-2,33-37$ & 4 & - & 45 & - & 10 & 1 & 24 & 2 & - & 1 & - & - & 13 & 1 & 1 & - & - & 1 & 91 & - & 8 \\
\hline $433 \mathrm{~A}-1-1,10-15$ & 17 & - & 5 & 1 & 14 & 12 & 32 & 7 & 1 & 1 & + & + & 23 & + & + & 1 & - & 1 & 77 & 1 & 17 \\
\hline $433 \mathrm{~A}-1-2,72-74$ & 2 & - & 61 & + & 2 & + & 9 & 2 & - & - & - & - & - & 8 & 2 & 8 & - & 22 & 35 & 1 & 23 \\
\hline $433 \mathrm{~A}-2-1,30-35$ & 16 & - & 8 & 1 & 14 & 16 & 31 & 4 & 1 & 1 & - & 8 & 13 & + & - & - & - & 20 & 12 & 59 & 8 \\
\hline $433 \mathrm{~A}-4-1,80-81$ & 15 & + & 40 & 1 & 1 & 6 & 13 & 2 & - & + & 1 & - & - & 1 & 1 & - & - & 36 & 14 & 38 & 10 \\
\hline $433 \mathrm{~A}-4-3,64-66$ & - & - & - & - & - & - & - & - & - & - & - & 2 & 2 & - & - & - & - & 2 & 10 & 86 & 2 \\
\hline $433 \mathrm{~A}-5-2,60-65$ & - & 17 & 72 & - & 1 & + & 5 & + & - & - & + & - & 53 & + & + & + & - & 3 & 84 & 3 & 2 \\
\hline $433 A-9-4,45-47$ & - & - & 45 & + & 1 & 2 & - & - & - & - & - & - & 8 & - & - & - & - & - & 100 & - & - \\
\hline $433 \mathrm{~A}-10-3,70-74$ & 9 & 19 & 37 & - & 2 & 11 & 12 & 1 & - & 1 & + & + & 12 & 6 & 2 & 6 & - & 12 & 57 & - & 17 \\
\hline $433 \mathrm{~A}-13-1,30-36$ & 1 & 40 & 38 & - & 1 & 4 & 3 & 1 & 1 & - & -- & - & 11 & + & 1 & - & + & + & 97 & - & \\
\hline $433 \mathrm{~A}-19-1,32-37$ & 1 & 3 & 86 & - & + & 1 & 7 & - & - & - & - & - & 1 & 2 & - & - & 26 & 7 & 55 & 3 & - \\
\hline $433 \mathrm{~B}-2-1,19-23$ & 4 & 33 & 52 & - & 1 & 1 & 2 & 1 & 1 & - & + & - & 5 & - & - & - & - & - & 100 & - & - \\
\hline
\end{tabular}

a few colorless and light brown glass shards, along with hornblende, biotite, plagioclase, epidote, and several other heavy minerals. We also found glass (very scarce) in smear slides from Sections 433A-3-1 and 433A-5-1. Altered basaltic (?) glass occurs in Sample 4-2, 50-55 $\mathrm{cm}$.

The coarse $(0.1$ to $0.05 \mathrm{~mm})$ light fraction separated from the diatom-nannofossil ooze of Cores $433 \mathrm{~A}-1$ to $433 \mathrm{~A}-5$ (Table 1 ) contains 12 to 36 per cent acidic volcanic glass with a low refraction index (less than 1.54). The glass predominates over other light clastic mineral grains, which are feldspar, quartz, and aggregates (including green chlorite or glauconite aggregates). In the heavy fraction, pyroxenes (perhaps volcanic) predominate; clinopyroxene (augite) is approximately twice as abundant as orthopyroxene (hypersthene). Most of other heavy minerals - hornblende, garnet, zircon, epidote, apatite, sphene - are probably terrigenous.

We have not noted any chemical evidence of basaltic volcaniclastic matter or its alteration products in the upper Pliocene portion of the pelagic sequence (Murdmaa et al., this volume). The Al:Ti ratio is high (24 to 34 ), and indicates acidic rather than basaltic volcaniclastics. In Cores 4 and 5, this ratio decreases somewhat (16 to 18 ), and we assume that a minor admixture of basaltic products may be present. Smear-slide data confirm this.

Sample 433A-6-7, 44-46 cm contains lower Miocene siliceous-calcareous ooze, transitional from a pelagic to a shallow-water ooze, and composed of nannofossils, spicules, radiolarians, palagonite, altered basaltic grains, and scarce heavy minerals (clinopyroxene, biotite). Its bulk chemical composition (Murdmaa et al., this volume) shows a low Al:Ti ratio (9), indicating basaltic volcaniclastics. The basaltic particles, however, are epiclastic, sub-rounded, and reworked during transportation in high-energy bottom waters. Deposition took place probably on an upper slope.
In the Paleocene to Eocene shallow-water sediments (Unit 5), volcanic clasts occur occasionally in trace quantities, as noted by the shipboard scientists. We also found scarce altered basaltic volcanic glass (palagonite?) in most smear slides of the sequence. A relatively low $\mathrm{Al}$ :Ti ratio (10 to 16$)$ provides additional evidence of basaltic matter. It is most abundant in the calcareous interbed between two lava flows (Section 433C-3-3), where the Al:Ti ratio is lowest (5.9). In Sample 433A-19-1, 32-37 cm, abundant zeolites (phillipsite) occur in the light fraction (Table 1).

\section{CONCLUSIONS}

In the Paleogene shallow-water sediments, which were deposited on the seamounts simultaneously with basaltic volcanism or just after its cessation, the volcaniclastic admixture is entirely of basaltic composition, and was probably derived from local sources. Most of the basaltic matter in these sediments is epiclastic, previously weathered, and partly rounded in an active wave environment.

Fine-grained acidic tephra, derived from island arc volcanoes, was found only in upper Miocene to Pliocene pelagic sediments, but even there only in small quantities. Ash layers, which are widespread in the North Pacific abyssal floor hemipelagic sediments (Hays and Ninkovich, 1970; Repechka, 1974) and in Bering Sea sediments (Hein et al., 1978) were not found on the seamounts.

\section{ACKNOWLEDGMENTS}

This paper was reviewed by Dr. G. N. Baturin and Prof. A. P. Lisitsin, both of the Institute of Oceanology, Academy of Sciences of U.S.S.R., Moscow, U.S.S.R.

\section{REFERENCES}

Hays, J. D. and Ninkovich, D., 1970. North Pacific deep-sea ash chronology and age of present Aleutian underthrusting. 
In Geological Investigation of the North Pacific: Geol. Soc. Am. Mem. 126, p. 263-289.

Hein, J. R., Scholl, D. W., and Miller, J., 1978. Episodes of Aleutian ridge explosive volcanism, Science, v. 199, p. 137141.
Repechka, M. A., 1974. Ash layers in bottom sediments in the transitional zone between Asian continent and Pacific. In The Problems of Geology and Geophysics of the Marginal Seas of NW Pacific: Vladivostok, p. 26-41 (in Russian). 